\title{
Simultaneous Separation and Quantification of Iron and Transition Species Using LC-ICP-MS
}

\author{
Qinhong Hu \\ Department of Earth and Environmental Sciences, The University of Texast, Arlington, USA \\ E-mail:maxhu@uta.edu
}

Received June 27, 2011; revised July 28, 2011; accepted August 5, 2011

\begin{abstract}
Using liquid chromatography-inductively coupled plasma-mass spectrometry (LC-ICP-MS), this work investigates the simultaneous separation and quantification of seven transition metal species (Fe, Mn, Co, Ni, $\mathrm{Cu}$, $\mathrm{Zn}$, and $\mathrm{Cd}$ ), based on a separation scheme published by Dionex company that used the spectrophotometric method for quantification. The LC-ICP-MS method overcomes the shortcomings of conventional ferrozine approaches of measuring Fe(II) and total Fe by two separate runs and calculating Fe(III) by the difference of two runs. The advantage is particularly evident in that organo-iron species are found to be the predominant iron species in many natural waters, and the difference method cannot measure the concentration of $\mathrm{Fe}(\mathrm{III})$ because ferrozine will not complex with organo-iron species. In the work reported here, the LC-ICP-MS method is successfully applied to the separation of dissolved iron species, as well as six other divalent transition metals in tap water, deionized water, river water, hot springs, and groundwater samples.
\end{abstract}

Keywords: LC-ICP-MS, Fe(II), Fe(III), Organo-Fe, Transition Metals

\section{Introduction}

Concentration determination of soluble reactive species is key to understanding biogeochemical processes in aquatic and terrestrial environments. Iron is one of the most reactive elements in aquatic and geological environments, and is involved in the cycling of many major chemicals, as well as trace elements [1]. For example, hydrous ferric oxides (e.g., ferrihydrite) are the most reactive soil components with respect to arsenic sorption and can take up hundreds of $\mathrm{mg} / \mathrm{kg}$ As, either as As(III) or $\mathrm{As}(\mathrm{V})$ [2]. The reduction of Fe oxyhydroxides and release of arsenic has been invoked as a probable mechanism of elevated As concentration in groundwater used for drinking and responsible for the poisoning of millions of people $[3,4]$.

Iron is present in the hydrosphere under two oxidation states, $\mathrm{Fe}(\mathrm{II})$ and $\mathrm{Fe}(\mathrm{III})$, which are thermodynamically stable under anoxic and oxic conditions, respectively [5]. Measurements of both dissolved Fe(II) and Fe(III) concentration are important in assessing iron's contribution in mediating numerous biogeochemical processes that involves many elements [6]. Most analytical approaches require a separate analysis of dissolved $\mathrm{Fe}(\mathrm{II})$ and total dissolved Fe, and the calculation of Fe(III) by the differ- ence [4]. First proposed by Stookey [7], the ferrozine (monosodium salt hydrate of 3-(2-pyridyl)-5, 6-diphenyl1,2,4-triazine-p, p'-disulfonic acid) method is the most widely-used way of determining $\mathrm{Fe}(\mathrm{II})$ and $\mathrm{Fe}(\mathrm{III})$. Ferrozine reacts with $\mathrm{Fe}(\mathrm{II})$ to form a stable magenta complex species, with a maximum absorbance at $562 \mathrm{~nm}$, which is measured spectrophotometrically. When Fe(III) is also present in the aqueous samples, either as a true dissolved complex or in colloids, a separate reduction step with hydroxylamine $\left(\mathrm{NH}_{4} \mathrm{OH} \cdot \mathrm{HCl}\right)$ is performed to measure the total iron, with the difference ascribed to Fe(III) $[5,6]$. The approach lacks sufficient sensitivity for determining iron concentrations in natural waters at $\mu \mathrm{g} / \mathrm{L}$ levels, and therefore a pre-concentration is usually required.

Alternative approaches to the ferrozine method have been proposed [6,8,9]. Yan [6] reported a method of on-line coupling of flow injection separation and preconcentration with ICP-MS, with a sample volume of 2.5 $\mathrm{mL}$ and detection limit of $0.08 \mu \mathrm{g} / \mathrm{L}$. However, the concentration of $\mathrm{Fe}(\mathrm{II})$ was obtained as the difference between the combined $\mathrm{Fe}(\mathrm{III})$ and $\mathrm{Fe}(\mathrm{II})$, and $\mathrm{Fe}(\mathrm{III})$ alone. This was done by controlling the sample acidity range, and detecting the $\mathrm{Fe}(\mathrm{III})$ by the $\mathrm{Fe}(\mathrm{III})$-pyrrolidinecarbodithioate (PDC) complex. In summary, relatively little 
has been published on the simultaneous measurement of both $\mathrm{Fe}(\mathrm{II})$ and $\mathrm{Fe}(\mathrm{III})$ in a single run.

Metal ions can exist in several different forms, which are determined by the extent of complexation and the oxidation state. In many aqueous samples, metal ions are present in their hydrated forms. Hydrated metal ions can also be complexed by weak ligands such as organic acids or amino acids. These ligands are generally displaced by the complexing agents used in liquid chromatography eluents, with the total of both hydrated and weakly complexed metal ions determined [10]. Hydrated and weakly complexed transition metals can be separated as cations on a cation exchange column. By adding a carboxylic acid chelating agent to the eluent, the net charge on the metal is reduced, because the carboxylic acids are anionic in solutions above their pKas. The selectivity of the separation is related to the different degrees of association between the metals and the chelating agents producing different net charges on the metal complexes. If strong enough chelating agents are used in high enough concentration, the net charge of the metal complexes can be negative. The resultant anionic metal complexes can be separated by an anion exchange process. The Dionex IonPac ${ }^{\circledR} \mathrm{CS}-5 \mathrm{~A}$ column has both cation and anion exchange capacities, allowing metals to be separated as cations or anions on a single column. The $9 \mu \mathrm{m}$ polymeric pellicular packing of the CS-5A column has an ethylene-vinylbenzene divinylbenzene resin core, 55\% cross-linking, consisting of two layers of latex particles, functionalized with both anion exchange alkyl quarternary amine (internal layer) and cation exchange sulfonic acid groups (outer layer), with capacities of 40 and 20 uequivalents, respectively. With pyridine-2, 6-dicarboxylic acid (PDCA) used as the chelating agent in the eluent, the transition metals are separated as anionic complexes in the analytical column of the IonPac CS-5A [10].

The following seven transition metals can be separated and quantified: iron, both ferric $\left(\mathrm{Fe}^{3+}\right)$ and ferrous $\left(\mathrm{Fe}^{2+}\right)$, divalent cations of copper, nickel, zinc, cobalt, cadmium, and manganese [10]. The present study was primarily focused on the separation of iron species, as well as the detection and prevalence of organo-Fe species in natural waters. However, the separation of the other six transition metals will also be described in this paper, and some examples of applications in natural waters will be given.

\section{Materials and Methods}

Except for $\mathrm{Fe}^{2+}$ and $\mathrm{Fe}^{3+}$, transition metal standards of $1000 \mathrm{mg} / \mathrm{L}$ were obtained from CPI International (Santa Rosa, CA). These stock solutions were purchased in dilute acid (1\% - 2\% nitric acid) solutions and diluted to different concentrations in deionzied (DI) water for LC-
ICP-MS analyses. Ferrous ammonium sulphate (Mohr's salt, $\left.\left[\mathrm{NH}_{4}\right]_{2}[\mathrm{Fe}]\left[\mathrm{SO}_{4}\right]_{2} \cdot 6 \mathrm{H}_{2} \mathrm{O}\right)$ was purchased from Alfa Aesar (Ward Hill, MA) and ferric chloride hexahydrate (iron III) from Mallinckrodt Baker (Phillipsburg NJ). These chemicals were used to prepare the standard solutions for Fe(II) and Fe(III), respectively. Each individual transition metal was prepared to obtain the retention time from LC separation for peak identification. All solutions were prepared using purified deionzied (DI) water (Milli-Q Ultrapure Water Purification System, Millipore, Billerica, MA).

As reported in Dionex (2011), the eluent for separating the transition metals includes the following mixture: 7.0 $\mathrm{mM}$ (PDCA), $66 \mathrm{mM}$ potassium hydroxide, $74 \mathrm{mM}$ formic acid, $5.6 \mathrm{mM}$ potassium sulfate. Dionex carries the MetPac $^{\text {TM }}$ PDCA eluent concentrate, which is to be diluted 5 times with $200 \mathrm{~mL}$ of the concentrate added with $800 \mathrm{~mL}$ DI water to make up 1-L eluent. To adjust the complexing ability of PDCA to optimize the separation time, we also purchased the individual chemicals in making the eluent: PDCA from Alfa Aesar (Ward Hill, MA), potassium hydroxide from EMD Chemicals (Gibbstown, NJ), formic acid from EMD Chemicals, and potassium sulfate from Mallinckrodt Baker (Phillipsburg NJ).

Both ferrous and ferric ions can be separated under the above separation conditions, using PDCA as the chelating agent to form anionic complexes. Because the ferrous ion is easily oxidized to ferric iron, oxygen was removed from the eluent by degassing the eluent solution bottle with helium for half an hour. To remove oxygen from the analytical and guard columns, a solution of $0.1 \mathrm{M}$ sodium sulfite (12.6 g/L Na $\mathrm{SO}_{3}$ ) was pumped through the columns for 2 hours before the sample analysis [10].

We used an advanced analytical method of LC-ICPMS for separating and quantifying iron, and the other 6 transition metal species, by modifying the quantification method of Dionex [10], to enable sensitive and simultaneous analyses in aqueous samples. Briefly, the LC system consisted of a PerkinElmer Series 200 Quaternary Pump and a Series 200 Autosampler (PerkinElmer/ SCIEX, Sheldon, CT) with an IonPac CS5A analytical and CG5A guard columns from Dionex (Sunnyvale, CA). Separation conditions included the following: mobile phase of MetPac PDCA eluent mixture at $\mathrm{pH}$ of 4.2 (adjusted with ammonium hydroxide, with $20 \%-22 \% \mathrm{NH}_{3}$ ), flow rate $1.2 \mathrm{~mL} / \mathrm{min}$, and sample injection volume 50 $\mu \mathrm{l}$.

In the Technical Note of Dionex [10], the metal complexing agent 4-(2-pyridylazo) resorcinol (PAR) is added postcolumn to form a light-absorbing complex with the hydrated and weakly complexed metals. These transition metals are detected by measuring the absorbance at 530 $\mathrm{nm}$ of the complex. We used the ICP-MS for sensitive 
determination of transition metal species. The effluent from the LC column was directly connected, via $60 \mathrm{~cm}$ of trifluoroacetic acid capillary tubing $(1.6 \mathrm{~mm}$ o.d. $\times 0.5$ $\mathrm{mm}$ i.d.), to the nebulizer of a PerkinElmer/SCIEX ELAN DRC II (Sheldon, CT) for the determination of transition metal concentration. The sample introduction system components of the ICP-MS consisted of a cyclonic spray chamber, a Meinhard ${ }^{\circledR}$ type A nebulizer, and platinum cones.

\section{Results and Discussion}

\subsection{Stability of $\mathrm{Fe}(\mathrm{II})$ and $\mathrm{Fe}(\mathrm{III})$ Solutions}

We used the DRC (Dynamic Reaction Cell) capability of ELAN DRC II ICP-MS, with ammonium as the reaction gas at a flow rate of $0.75 \mathrm{~L} / \mathrm{min}$ and rejection parameter $\mathrm{RPq}$ of 0.45 , to minimize the polyatomic interference of ${ }^{40} \mathrm{Ar}^{16} \mathrm{O}$ to ${ }^{56} \mathrm{Fe}$ [11-14]. From the monitored signal intensity results at the atomic mass unit of 56 with only the eluent passing through the column, we observed a baseline level at 22,000 cps (counts per second) under the DRC condition (Figure 1(a)), compared to 240,000 cps at the standard mode (i.e., no DRC). A factor of 10 times reduction of baseline level is critical for sensitive measurements of ${ }^{56} \mathrm{Fe}$.

We next focused on the standards of both $\mathrm{Fe}(\mathrm{III})$ and $\mathrm{Fe}(\mathrm{II})$ prepared from $\mathrm{FeCl}_{3}$ and $\left[\mathrm{NH}_{4}\right]_{2}[\mathrm{Fe}]\left[\mathrm{SO}_{4}\right]_{2} \cdot 6 \mathrm{H}_{2} \mathrm{O}$. $\mathrm{Fe}(\mathrm{III})$ standards from $\mathrm{FeCl}_{3}$ chemicals exhibited only an Fe(III) peak, as shown in Figure 1(b), where the chromatogram for $1000 \mathrm{mg} / \mathrm{L}$ solution of Fe(III) was accompanied by only a very small peak at the retention time of $\mathrm{Fe}(\mathrm{II})$. However, $\mathrm{Fe}(\mathrm{II})$ standard prepared from ammonium iron(II) sulfate $\left(\left[\mathrm{NH}_{4}\right]_{2}[\mathrm{Fe}]\left[\mathrm{SO}_{4}\right]_{2} \cdot 6 \mathrm{H}_{2} \mathrm{O}\right.$, Mohr's salt) chemicals essentially only shown an Fe(III) peak (Figure 2(a)), indicating the oxidation of $\mathrm{Fe}(\mathrm{II})$ chemicals over time. Supposedly, Mohr's salt is preferred over iron(II) sulfate as it is much less affected by oxygen in the air than iron(II) sulfate, solutions of which tend to oxidize to iron(III). The oxidation of solutions of iron(II) is very $\mathrm{pH}$ dependent, occurring much more readily at high $\mathrm{pH}$. The ammonium ions make solutions of Mohr's salt slightly acidic, which prevents this oxidation from occurring.

We used a reducing agent, $0.1 \mathrm{M} \mathrm{NH}_{2} \mathrm{OH} \cdot \mathrm{HCl}$, and boiling condition [15] to treat the solution prepared from Mohr's salt, and stored the resultant standard of 1000 $\mathrm{mg} / \mathrm{L}$ in an autoclaved amber glass bottle.

Standards of $\mathrm{Fe}(\mathrm{II})$ with different concentrations were prepared from a working standard of $100 \mathrm{mg} / \mathrm{L} \mathrm{Fe}(\mathrm{II})$ for LC-ICP-MS studies. Figure 2(b) shows the Fe(II) peak, with a negligible $\mathrm{Fe}(\mathrm{III})$ peak which likely is caused by the DI water used in standard preparation (to be dis-

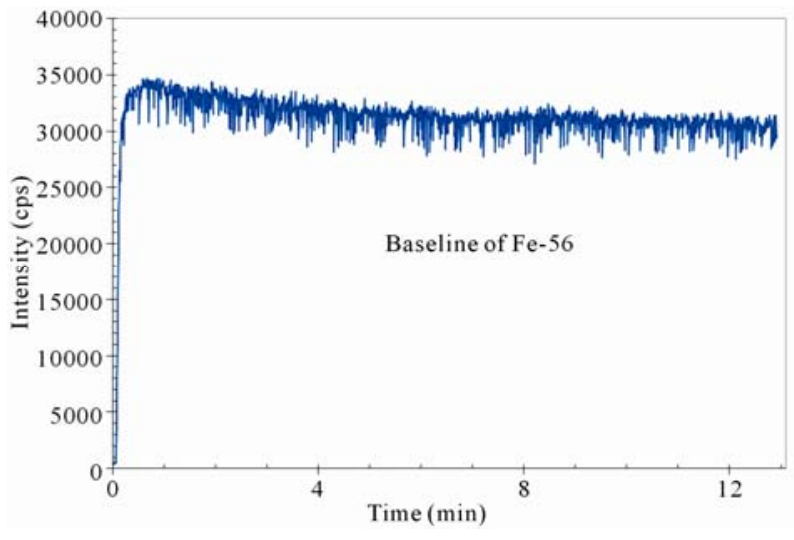

(a)

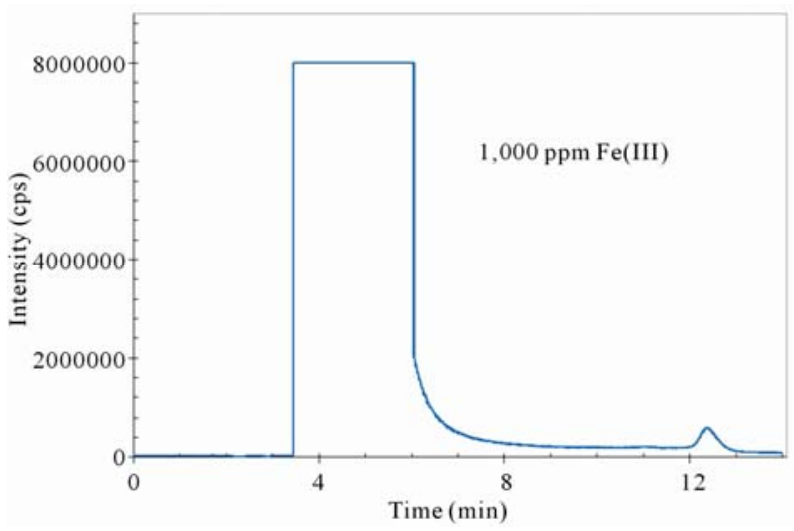

(b)

Figure 1. (a) LC-ICP-MS ${ }^{56} \mathrm{Fe}$ signal intensity baseline of the eluent solution; (b) Signal intensity of Fe(III), at the retention time around 4 min, prepared from $\mathrm{FeCl}_{3}$ chemicals indicating minimal presence of $\mathrm{Fe}(\mathrm{II})$ with a retention time of $\mathbf{1 2 . 5} \mathbf{~ m i n}$.

cussed later), of the $100 \mathrm{mg} / \mathrm{L} \mathrm{Fe}(\mathrm{II})$ working standard.

Figure 3 shows the chromatograms of mixed standards of $\mathrm{Fe}(\mathrm{II})$ and $\mathrm{Mn}(\mathrm{II})$ at different concentrations. Compared with 24,000 cps background level for ${ }^{56} \mathrm{Fe}$, the background for ${ }^{55} \mathrm{Mn}$ is only at about $800 \mathrm{cps}$, indicating much lower polyatomic interference for Mn detection. Multiple measurements of $0.5 \mu \mathrm{g} / \mathrm{L}$ Fe(II) exhibit somewhat different peak height (and area), indicating that the detection limit for Fe(II) by the LC-ICP-MS method is slightly higher than $0.5 \mu \mathrm{g} / \mathrm{L}$ (Figure 3(a)). However, this is still a simple and versatile method to measure simultaneously both $\mathrm{Fe}(\mathrm{II})$ and $\mathrm{Fe}(\mathrm{III})$ at low $\mu \mathrm{g} / \mathrm{L}$ concentration levels. In addition, all chromatograms show sharp peaks with reproducible retention times for $\mathrm{Fe}(\mathrm{II})$, $\mathrm{Fe}(\mathrm{III})$, and $\mathrm{Mn}(\mathrm{II})$ species (Figure 3). Furthermore, there are $\mathrm{Fe}(\mathrm{III})$ peaks reaching 120,000 cps levels from all standards of $\mathrm{Fe}(\mathrm{II})$ and $\mathrm{Mn}(\mathrm{II})$; this level of $\mathrm{Fe}(\mathrm{III})$ probably originates from the DI water used for standard preparation. 


\subsection{Prevalence of Organic-Fe Species in Natural Samples}

The Technical Note of Dionex [10] describes the use of 7 mM PDCA as the complexing agent for seven transition metals, with $\mathrm{Fe}(\mathrm{III})$ appearing first and $\mathrm{Fe}(\mathrm{II})$ last in the chromatograms. We tested the effect of PDCA concentration on the retention time of $\mathrm{Fe}$, as well as that of other transition metal species; the results are shown in Table 1.

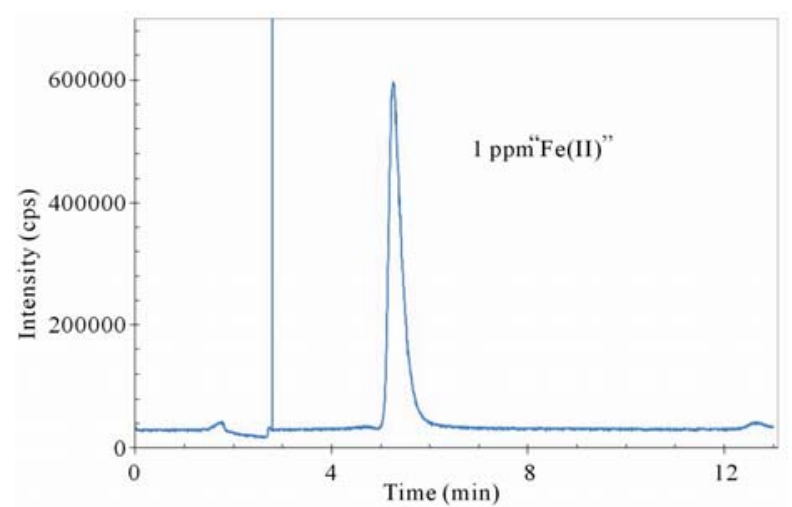

(a)

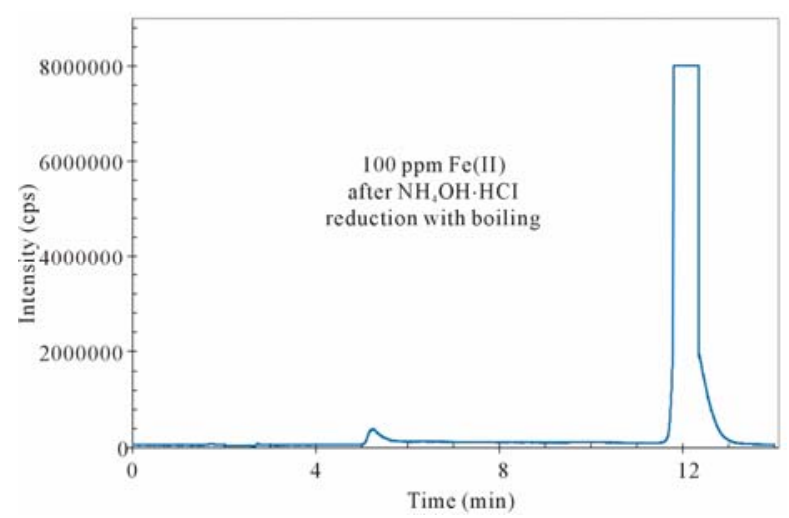

(b)

Figure 2. (a) $\mathrm{Fe}$ (II) standard prepared from untreated $\left[\mathrm{NH}_{4}\right]_{2}[\mathrm{Fe}]\left[\mathrm{SO}_{4}\right]_{2} \cdot 6 \mathrm{H}_{2} \mathrm{O}$ chemical indicating its oxidation to $\mathrm{Fe}(\mathrm{III})$; (b) $\mathrm{Fe}(\mathrm{II})$ standard solution obtained from reductant $\mathrm{NH}_{4} \mathrm{OH} \cdot \mathrm{HCl}$ under boiling condition.

Table 1. PDCA concentration and associated retention of iron species.

\begin{tabular}{ccc}
\hline PDCA & $\begin{array}{c}\text { Species and retention } \\
\text { time (min) }\end{array}$ & Note \\
\hline $3.5 \mathrm{mM}$ & $\mathrm{Fe}^{3+}(7.0)$ & Too long separation time \\
$7.0 \mathrm{mM}$ & $\begin{array}{c}\text { organo-Fe }(2.8) ; \mathrm{Fe}^{3+} \\
(5.0) ; \mathrm{Fe}^{2+}(11.2)\end{array}$ & $\begin{array}{c}\text { Reasonable } \\
\text { separation time }\end{array}$ \\
$14 \mathrm{mM}^{@}$ & $\begin{array}{c}\text { organo-Fe }(2.1) ; \mathrm{Fe}^{3+} \\
(3.8) ; \mathrm{Fe}^{2+}(6.5)\end{array}$ & $\begin{array}{c}\text { Best scheme for separating all } \\
7 \text { transition metals in } 8 \mathrm{~min}\end{array}$ \\
\hline
\end{tabular}

${ }^{\circledR}$ Preparation of $14 \mathrm{mM}$ pyridine-2, 6-dicarboxylic acid (PDCA), $66 \mathrm{mM}$ potassium hydroxide, $74 \mathrm{mM}$ formic acid, and $5.6 \mathrm{mM}$ potassium sulfate: warm the solution to fully dissolve PDCA; the measured $\mathrm{pH}$ is 3.58; add about $10 \mathrm{~mL}$ concentrated $\mathrm{NH}_{4} \mathrm{OH}$ into $4 \mathrm{~L}$ eluent solution to adjust $\mathrm{pH}$ to 4.22; otherwise, the baseline is not stable in LC-ICP-MS runs.

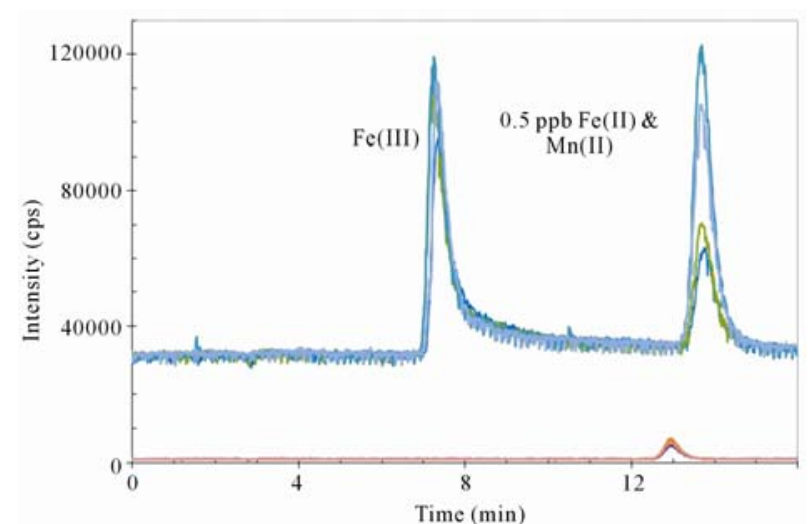

(a)

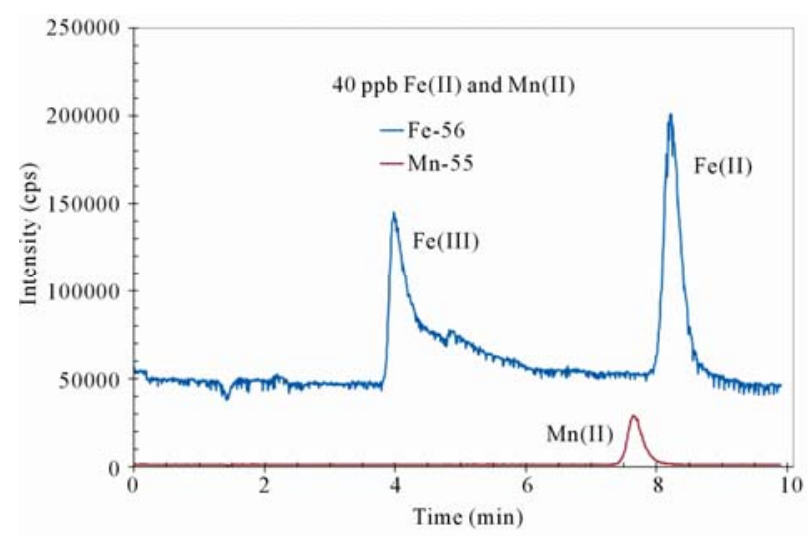

(b)

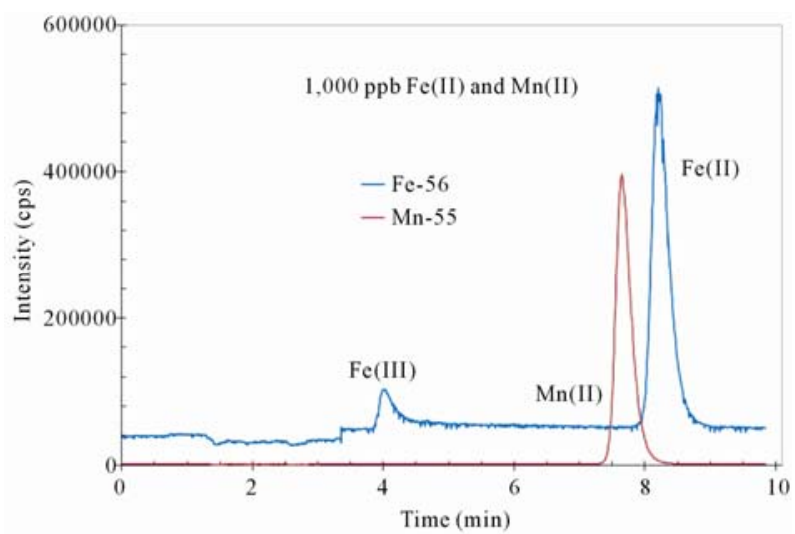

(c)

Figure 3. Signal responses of $\mathrm{Fe}(\mathrm{II})$ and $\mathrm{Mn}(\mathrm{II})$ standard solutions at the concentration of (a) $0.5 \mu \mathrm{g} / \mathrm{L}$ (four duplicate injections are presented); (b) $40 \mu \mathrm{g} / \mathrm{L}$; and (c) $1000 \mu \mathrm{g} / \mathrm{L}$. Slightly different PDCA concentrations (Table 1) were used to produce different retention times.

It was observed that a lower PDCA concentration will lead to a longer retention time in the separation condition. We suggest the use of a concentration of $14 \mathrm{mM}$ PDCA to reduce the run time to less than eight minutes for the separation of all 7 transition metal species; note that 
some figures shown in this work were obtained at a lower PDCA concentration; this had no effect on the interpretation of results, although the chromatograms show a longer run time (e.g., $12 \mathrm{~min}$ ). An adjustment of $\mathrm{pH}$ to 4.22 is necessary to produce a stable baseline in the eluent mixture of $14 \mathrm{mM}$ PDCA, since PDCA is slightly acidic, with a measured $\mathrm{pH}$ of 2.38 for the14 mM PDCA solution.

Figure 4 shows example chromatograms for groundwater and river water samples collected in Texas; the samples were filtered through a $0.25 \mu \mathrm{m}$ membrane filer with no other preservation step (e.g., acidification), and stored at $4^{\circ} \mathrm{C}$ in a refrigerator. Both samples show a small $\mathrm{Fe}(\mathrm{III})$ peak and no $\mathrm{Fe}(\mathrm{II})$, while the groundwater shows $\mathrm{Mn}$ (II) presence. In addition, both samples show a large ${ }^{56} \mathrm{Fe}$ peak before the ${ }^{56} \mathrm{Fe}(\mathrm{III})$ peak; this is likely related to an organic-Fe species, such as an Fe-complex with natural organic matter (NOM). Typically, NOM is a complex mixture of organic substances containing a variety of functional groups, such as carboxyls, phenols, thiols and amines, many of which interact strongly with Fe(II) and/or $\mathrm{Fe}(\mathrm{III})$. It has been reported that $\mathrm{Fe}(\mathrm{III})$ forms

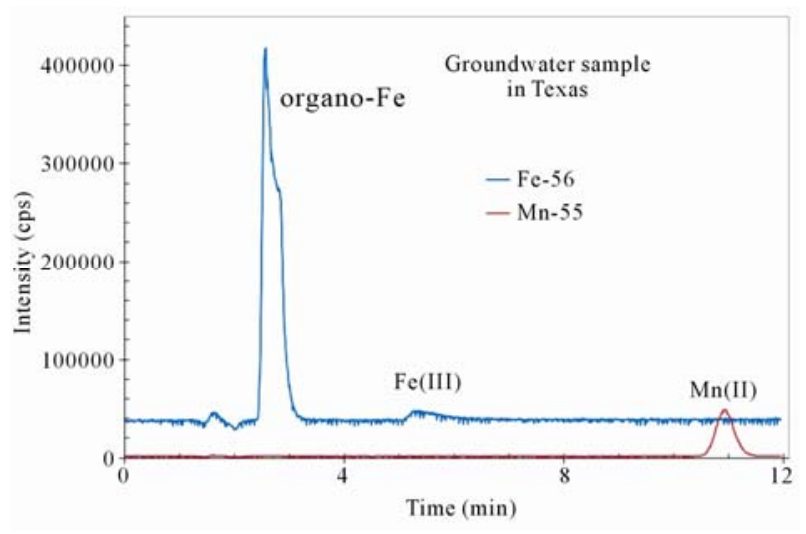

(a)

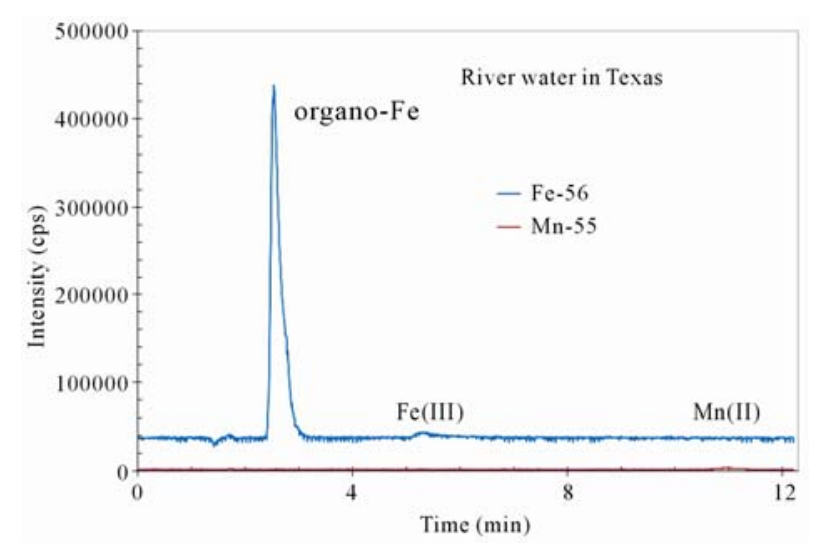

(b)

Figure 4. Detection of iron species and Mn(II) in (a) groundwater; and (b) river water samples in Texas. complexes with organic acids. At low Fe concentrations and $\mathrm{pH} 3.0$ - 7.2, mononuclear Fe(III)-NOM complexes completely dominate the speciation, and a substantial amount of the total $\mathrm{Fe}(>50 \%)$ is in the form of organic complexes [16].

We further measured the Fe chromatograms of several solutions of organic materials containing $10 \mathrm{mg} / \mathrm{L}$ carbon; these solutions were prepared from the standard reference materials including Suwannee River natural organic matter, Suwannee River fulvic acid, Pahokee Peat humic acid, and Summit Hill soil humic acid (all from the International Humic Substances Society, Denver, CO). We consistently observed the organic-Fe peak for these four materials; the chromatograms of Suwannee River natural organic matter and Summit Hill soil humic acid are shown in Figure 5. The iron species in these solutions are predominantly organo-Fe.

In addition, we analyzed the effluent samples from columns packed with sediment samples, where we studied the transport behavior of arsenic species in different sediments [17]. We consistently observed the predominant organo-Fe peaks in the column effluents from both Hanford and Datong basin sediments (Figure 6). In a report on determination of the structures and reactivities of Fe associated with NOM (considering that these interactions influence the redox, hydrolysis and solubility of $\mathrm{Fe}^{18}$ ), Rue and Bruland [18] reported that $99.97 \%$ of the dissolved Fe(III) in central North Pacific surface waters is chelated by natural organic ligands. We are not aware of the direct detection, or of the prevalence and predominance, of organo-Fe species in natural water. It is important to note that the conventional ferrozine method of analyzing for $\mathrm{Fe}(\mathrm{III})$ is based on the difference of measured total $\mathrm{Fe}$ and $\mathrm{Fe}(\mathrm{II})$, and that the presence of organo-Fe species will affect the measurement of inorganic Fe species. As discussed above, iron forms complexes with dissolved organic matter; where this occurs

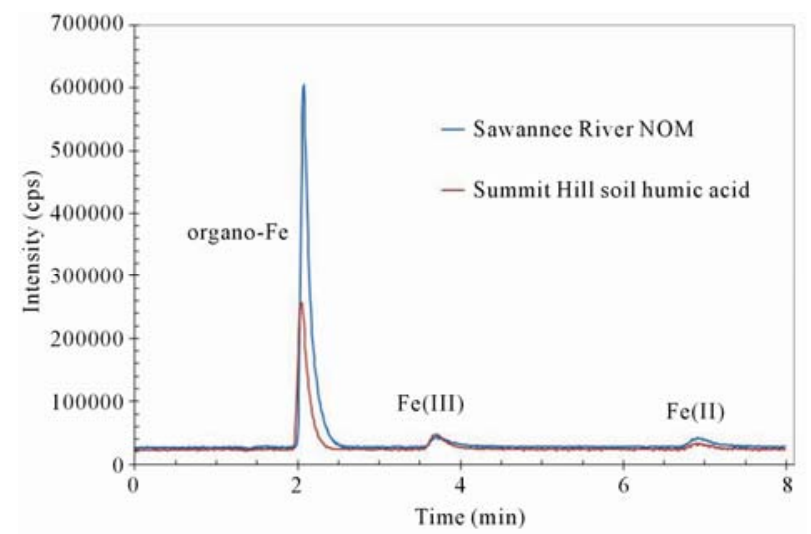

Figure 5. Detection of iron species in (A) Suwannee River natural organic matter; and (B) Summit Hill soil humic acid; both at the concentration of $10 \mathrm{mg} / \mathrm{L}$ carbon. 


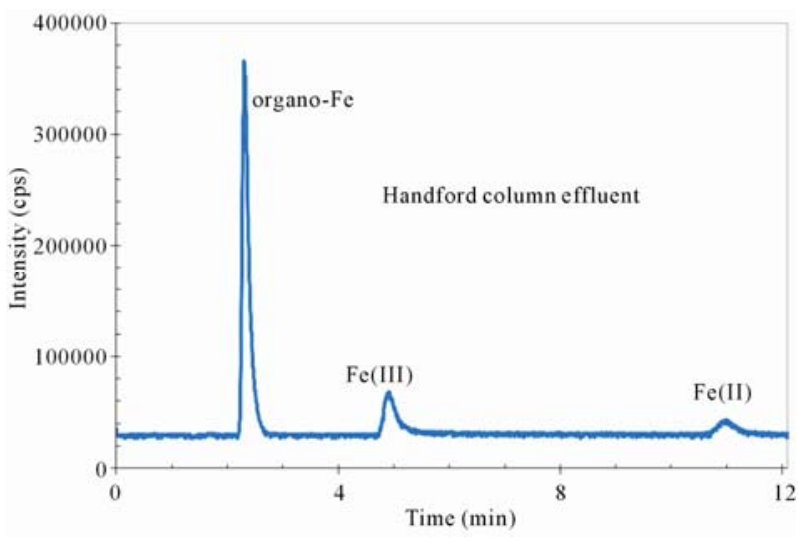

(a)

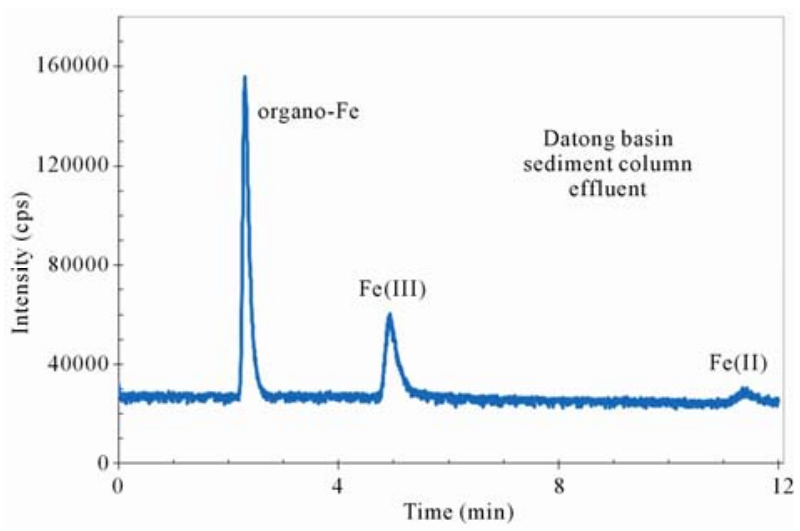

(b)

Figure 6. Detection of iron species and Mn(II) in the effluent samples collected from a column packed with (a) Hanford sediment in the State of Washington; and (b) Datong Basin in Shanxi province, China.

in seawater, the color development of ferrozine chelates is hindered. To eliminate this factor, samples were heated and exposed to UV irradiation to decompose the organo-iron complex in the work of Kononets et al. [19].

\subsection{Simultaneous Separation of Seven Transition Metals}

The separation scheme can detect seven transition metal species in a single run. Using individual standards, we obtained the retention times of these species in the eluent with 14 mM PDCA concentration (Figure 7, Table 2). Table 2 also presents the isotopes monitored for these seven transition metals, the baseline levels, and the intensity responses for these isotopes. Other than Fe-56 and $\mathrm{Cu}-63$, the isotopes for monitored transition metals have low mass interference. After normalizing the natural abundance for these isotopes, the signal intensities for all of these elements are fairly close (Table 2), which is expected from their closeness in atomic mass units

Using the separation method for seven transition metals, we further analyzed both the tap water and the DI water in a research lab; the DI water was produced bypassing the tap water through the water purification system, which consisted of reverse osmosis and a 254-nm UV lamp for organic molecule oxidation and bacteria destruction. We observed a peak of organo-Fe in the tap water, and this peak was removed in the DI water, possibly from the UV oxidation (Figure 8). On the other hand, the heights of $\mathrm{Fe}(\mathrm{III})$ and $\mathrm{Fe}(\mathrm{II})$ peaks are similar for both tap and DI waters, indicating the inefficiency of the water purification system to remove very low (below about $0.2 \mu \mathrm{g} / \mathrm{L}$ ) concentrations of these Fe species. The tap water also has higher concentrations of $\mathrm{Cu}$ and $\mathrm{Zn}$ than the DI water, probably from the piping system (Figure 8).

Water samples from the Gallinas River and the Montezuma Hot Springs in New Mexico also indicate the presence of organo-Fe, as well as Fe(III) and Fe(II), species (Figure 9). In addition, there is a detectable amount of divalent $\mathrm{Cu}, \mathrm{Ni}, \mathrm{Zn}$, and $\mathrm{Mn}$ species in these waters.

\section{Conclusions}

Using advanced analytical tools of LC-ICP-MS and modification of a separation scheme for seven transition metals published by Dionex, we present a versatile method of simultaneous analysis for iron species, with micro-liter injection volumes. The method is assisted by the use of the Dynamic Reaction Cell technique to reduce the detection of ${ }^{56} \mathrm{Fe}$, and the species check of

Table 2. Retention time and signal intensity of 7 transition metals simultaneously separated and quantified by LC-ICP-MS.

\begin{tabular}{|c|c|c|c|c|c|c|c|}
\hline & $\mathrm{Cu}-63$ & Ni-60 & Zn-66 & Co-59 & Cd-114 & Mn-55 & Fe(II)-56 \\
\hline Retention time (min) & 3.9 & 4.3 & 4.7 & 5.2 & 5.8 & 6.6 & 6.9 \\
\hline Natural abundance (\%) & 69.09 & 26.33 & 27.81 & 100 & 28.86 & 100 & 91.66 \\
\hline Baseline level (cps) & 25,000 & 2,600 & 1,100 & 140 & 110 & 800 & 25,000 \\
\hline LC-ICP-MS intensity of 1 ppm standard (cps) & $7,443,737$ & $2,753,464$ & $1,859,578$ & $10,385,828$ & $3,383,030$ & $14,665,378$ & $7,338,520$ \\
\hline Abundance normalized cps/ppb & 10,773 & 10,457 & 6,687 & 10,386 & 11,722 & 14,665 & 8,006 \\
\hline
\end{tabular}




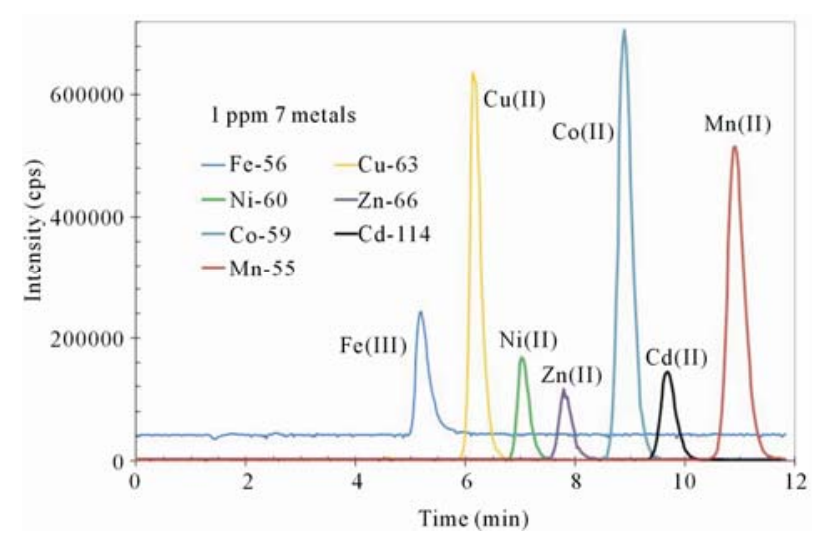

Figure 7. Retention times and signal intensities of 7 transition metals in a single run.

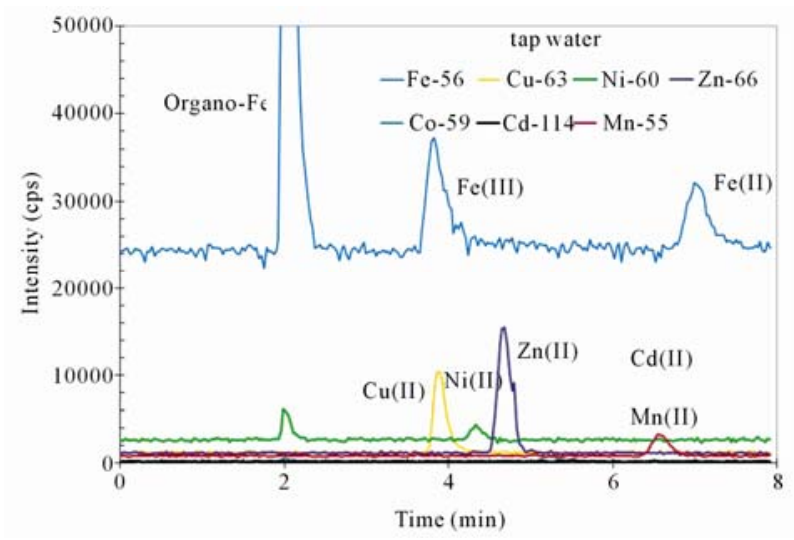

(a)

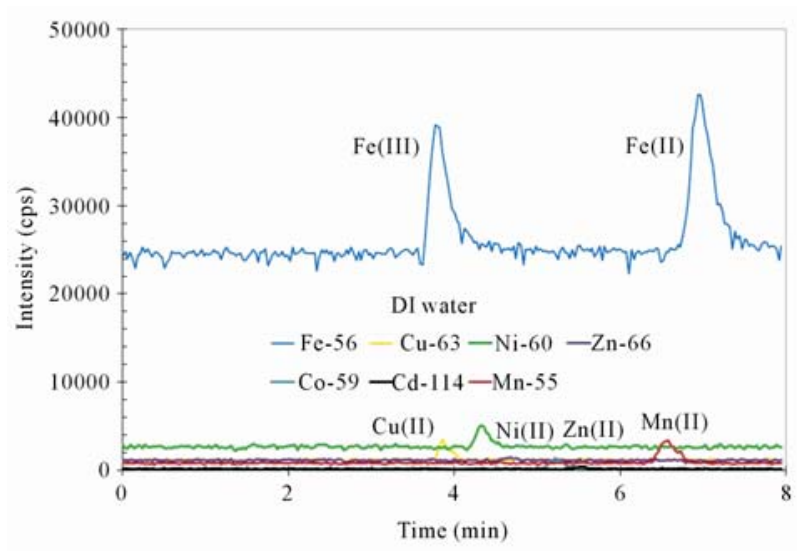

(b)

Figure 8. Presence of 7 transition metal species in the (a) tap water; and (b) DI water.

$\mathrm{Fe}(\mathrm{III})$ and $\mathrm{Fe}(\mathrm{II})$ increases the confidence of iron species determination. In particular, we found that most of the iron species in natural waters and geological samples could exist in complexation with natural organic matter. Attention should be paid to the prevalence of organo-Fe species in speciation studies of iron, and to its role in

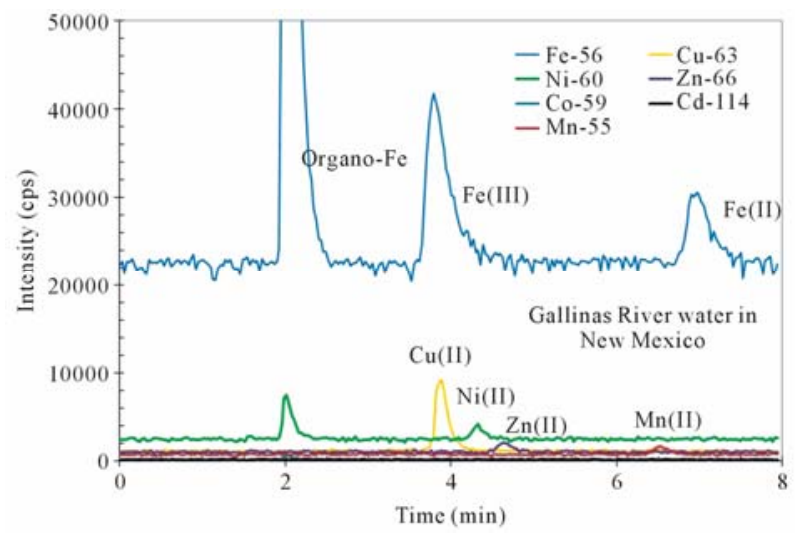

(a)

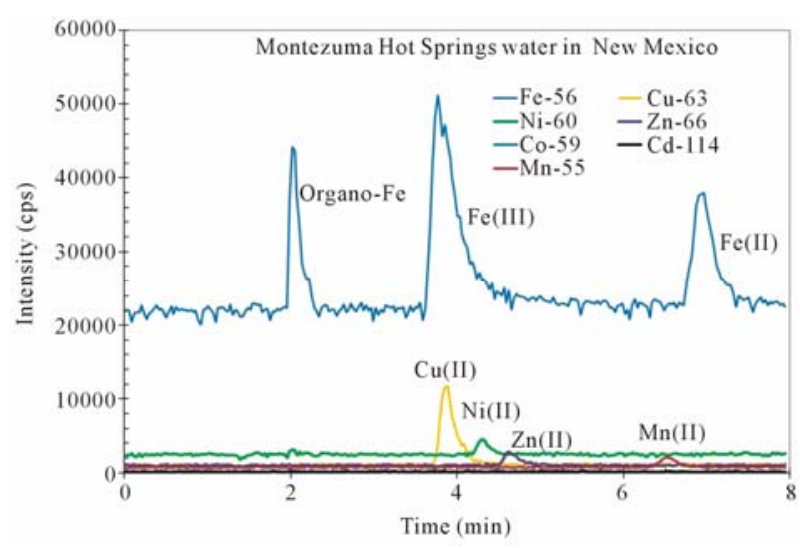

(b)

Figure 9. Presence of 7 transition metal species in (a) Gallinas River; and (b) Montezuma Hot Springs water samples in New Mexico.

modifying the biogeochemical cycling of elements in aquatic and terrestrial environments.

\section{Acknowledgments}

This work was financially supported by the University of Texas at Arlington.

\section{References}

[1] R. L. Loeppert and W. P. Inskeep, "Iron," Methods of Soil Analysis: Chemical Methods. Part 3. D. L. Sparks. Madison, Soil Science Society of American, Inc., 1996, pp. 639-664.

[2] S. Goldberg, "Competitive Adsorption of Arsenate and Arsenite on Oxide and Clay Minerals," Soil Science Society of American Journal, Vol. 66, No. 2, 2002, pp. 413-421.

[3] R. T. Nickson, J. M. McArthur, P. Ravenscroft, W. B. Burgess and K. M. Ahmed, "Mechanism of Arsenic Release to Groundwater, Bangladesh and West Bengal," Applied Geochemistry, Vol. 15, No. 4, 2000, pp. 403-413. 


\section{doi:10.1016/S0883-2927(99)00086-4}

[4] P. L. Smedley and D. G. Kinniburgh, "A Review of the Source, Behaviour and Distribution of Arsenic in Natural Waters," Applied Geochemistry, Vol. 17, No. 5, 2002, pp. 517-568. doi:10.1016/S0883-2927(02)00018-5

[5] E. Viollier, P. W. Inglett, K. Hunter, A. N. Roychoudhury and P. Van Cappellen, "The Ferrozine Method Revisited: $\mathrm{Fe}(\mathrm{II}) / \mathrm{Fe}(\mathrm{III})$ Determination in Natural Waters,” Applied Geochemistry, Vol. 15, No. 6, 2000, pp. 785-790. doi:10.1016/S0883-2927(99)00097-9

[6] X. P. Yan, N. J. Hendry and R. Kerrich, "Speciation of Dissolved Iron(III) and Iron(II) in Water by On-Line Coupling of Flow Injection Separation and Preconcentration with Inductively Coupled Plasma Mass Spectrometry," Analytical Chemistry, Vol. 72, No. 8, 2000, pp. 1879-1884. doi:10.1021/ac9909655

[7] L. L. Stookey, "Ferrozine a New Spectrophotometric ReAgent for Iron Determination,” Analytical Chemistry, Vol. 42, No. 7, 1970, pp. 779-784. doi:10.1021/ac60289a016

[8] L. S. Huang and K. C. Lin, "Detection of Iron Species Using Inductively Coupled Plasma Mass Spectrometry under Cold Plasma Temperature Conditions,” Spectrochim Acta Part B-Atomic Spectroscopy, Vol. 56, 2001, pp. 123-128. doi:10.1016/S0584-8547(00)00292-5

[9] D. L. Giokas, E. K. Paleologos and M. I. Karayannis, "Speciation of Fe(II) and Fe(III) by the Modified FerroZine Method, FIA-Spectrophotometry, and Flame AAS after Cloud-Point Extraction," Analytical and Bioanalytical Chemistry, Vol. 373, No. 4-5, 2002, pp. 237-243. doi:10.1007/s00216-002-1326-7

[10] Dionex, "Determination of Transition Metals by Ion Chromatography,” Technical Note 10, 2011.

http://wwwsearch.dionex.com/search?site=www\&client= www_frontend\&proxystylesheet $=$ www_frontend\&output =xml_no_dtd $\& \mathrm{q}=\operatorname{tn} 10$

[11] F. Vanhaecke, L. Balcaen, G. De Wannemacker and L. Moens, "Capabilities of Inductively Coupled Plasma Mass Spectrometry for the Measurement of Fe Isotope Ratios," Journal of Analytical and Atomic Spectrometry, Vol. 17, No. 8, 2002, pp. 933-943. doi:10.1039/b202409h
[12] K. Kawabata and Y. Kishi, "DRC-ICP-MS Analysis of Various Chemicals Used in the Semiconductor Industry (Reprinted with Permission from the Semiconductor Pure Water \& Chemicals Conference 2001)," Atomic Spectrometry, Vol. 24, No. 2, 2003, pp. 66-72.

[13] C. F. Yeh and S. J. Jiang, "Speciation of V, Cr and Fe by Capillary Electrophoresis-Bandpass Reaction Cell Inductively Coupled Plasma Mass Spectrometry," Journal of Chromatography A, Vol. 1029, No. 1-2, 2004, pp. 255261. doi:10.1016/j.chroma.2003.12.070

[14] S. D’Ilio, N. Violante, M. Di Gregorio, O. Senofonte and F. Petrucci, "Simultaneous Quantification of 17 Trace Elements in Blood by Dynamic Reaction Cell Inductively Coupled Plasma Mass Spectrometry (DRC-ICP-MS) Equipped with a High-Efficiency Sample Introduction System,” Analytical Chimica Acta, Vol. 579, No. 2, 2006, pp. 202-208. doi:10.1016/j.aca.2006.07.027

[15] G. G. Rao and G. Somidevamma, "Volumetric DetermiNation of Iron (III) with Hydroxylamine as a Reducing Agent," Fresenius' Journal of Analytical Chemistry, Vol. 165, No. 6, 1959, pp. 432-436.

[16] T. Karlsson and P. Persson, "Coordination Chemistry and Hydrolysis of Fe(III) in a Peat Humic Acid Studied by X-Ray Absorption Spectroscopy," Geochimica et Cosmochimica Acta, Vol. 74, 2010, pp. 30-40. doi:10.1016/j.gca.2009.09.023

[17] Q. H. Hu, G. X. Sun and X. B. Gao, "Conversion, Sorption, and Transport of Arsenic Species in Geological Media,” Applied Geochemistry, 2011 (under revision).

[18] E. L. Rue and K. W. Bruland, “Complexation of Iron(III) by Natural Organic-Ligands in the Central North Pacific as Determined by a New Competitive Ligand Equilibration Adsorptive Cathodic Stripping Voltammetric Method," Marine Chemistry, Vol. 50, No. 1-4, 1995, pp. 117-138. doi:10.1016/0304-4203(95)00031-L

[19] M. Y. Kononets, S. V. Pakhomova, A. G. Rozanov and M. A. Proskurnin, "Determination of Soluble Iron Species in Seawater Using Ferrozine,” Journal of Analytical Chemistry, Vol. 57, No. 7, 2002, pp. 586-589. doi:10.1023/A:1016269832258 